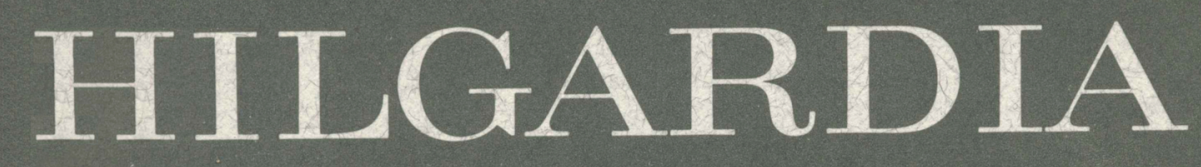

A JOURNAL OF AGRICULTURAL SCIENCE PUBLISHED BY THE CALIFORNIA AGRICULTURAL EXPERIMENTSTATION

Volume 41, Number $10 \cdot$ February, 1972

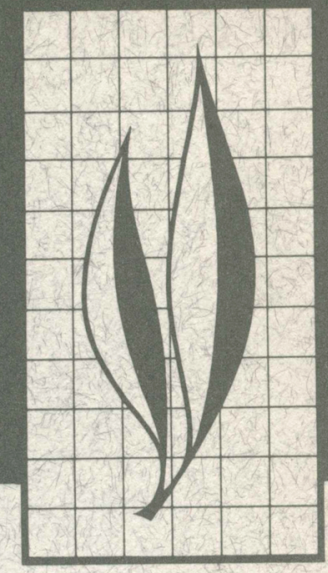

\title{
Some Factors Affecting Flow into Drainpipes
}

J. N. Luthin and A. Haig 


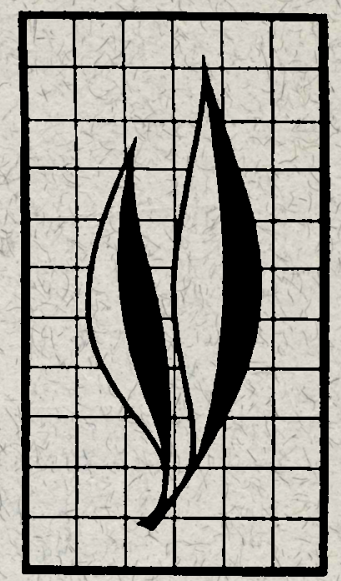

Factors influencing flow into subsurface drainpipes were investigated in an experimental tank. Where available and experimental results were compared to theory. It was found that doubling drain diameter from 2 to 4 inches increased the flow 35 to 60 per cent. An increase of drain diameter from 2 to 7.48 inches caused a 90 to 130 per cent increase in flow depending on the water-table height. Decreasing pipe-segment length from 3 to 1 foot increased the rate of flow into the pipe by $21 / 2$ times. Wrapping the pipe with glass fiber reduced the effect to about a 50 per cent increase.

Discharge rates are greater when the holes are at the bottom of the pipe because of the greater hydraulic head. When outflow is adjusted for the hydraulic head there is no difference due to location of holes. In all the measurements, except for the largest drain and for the lowest reservoir level, the water table did not intersect the drain but was above it even though the drains were not running full. The only observable effect of various water levels in the drains (open, one-quarter or one-half full) was due to a slight change in the total hydraulic head. The effect was negligible for the cases investigated. Flow into the drains was directly proportional to water-table height at the midpoint.

\section{THE AUTHORS:}

J. N. Luthin is Professor of Water Science and Civil Engineering, and Water Scientist in the Experiment Station, Davis.

A. Haig is Staff Research Associate IV, Department of Water Science and Engineering, Davis. 


\section{Some Factors Affecting Flow into Drainpipes ${ }^{1}$}

\section{INTRODUCTION}

FLow of WATER into subsurface drains is greatly influenced by hydraulic conditions immediately around the drain. Most of the loss in hydraulic head occurs in the immediate vicinity of the drain. Flow into the drain will be influenced by anything that affects the hydraulic head. Rate of flow into the drain is important because it is directly related to rate of fall of the water table. Water table recession is also related to drain spacing. Hence, factors affecting flow into the drain affect drain-spacing requirements and therefore the cost of drainage.

Various theoretical studies have been made of such flow either through mathematical analysis or analysis by the use of analogs. Schwab and Kirkham (1951) and Kirkham and Schwab (1951) analyzed the effect of perforation-spacing on flow into a drain located under a horizontal water table and they verified their equations with an electric analog. The results are valid only for a bare drainage pipe, no gravel envelope, a horizontal water table, and a drainpipe full of water.

Kirkham (1950) examined the effect of size of gap or opening between segmented drainpipes on flow into the pipe. Potential theory was used in the analysis, and the assumption was made that the drain flowed full with a horizontal water table. He showed that, with a drain of 6-inch diameter having 1 foot-long impermeable sections and buried four feet deep, increasing the gap from $1 / 32$-inch to $1 / 4$-inch increased flow 36 per cent, and that embedding the pipe in gravel increased flow 180 per cent.

Schwab et al. (1969) investigated the effect of spacing of holes in plastic pipe on flow into the drains. Experimental field data were compared with Kirkham's (1950) theoretical analysis. The results compared favorably to the theory, and they concluded that Kirkham's theory, developed for a flat water table, applies equally to the drawdown case.

The theoretical analyses have improved understanding of factors influencing flow into drains. Questions arise, however, concerning the effect of actual installed conditions of drain lines, and the effect of installation conditions on operation of the drain line. The experiments reported herein were performed to answer some of those questions. Some can be answered from theoretical considerations, but a doubt is always present as to applicability of the theory because of the assumed boundary conditions necessary to theoretical development. For example, in the actual field situation the water table is not flat and the drains are not necessarily running full.

Some questions considered here are the effects on flow into the drain of:

1. Drain diameter.

2. Pipe segment length (no envelope).

3. Pipe segment length (with envelope).

4. Placement of a single line of holes on top or bottom of drain.

5. Water-table height.

6. Water level in drain.

\footnotetext{
${ }^{1}$ Submitted for publication March 3, 1971.
} 


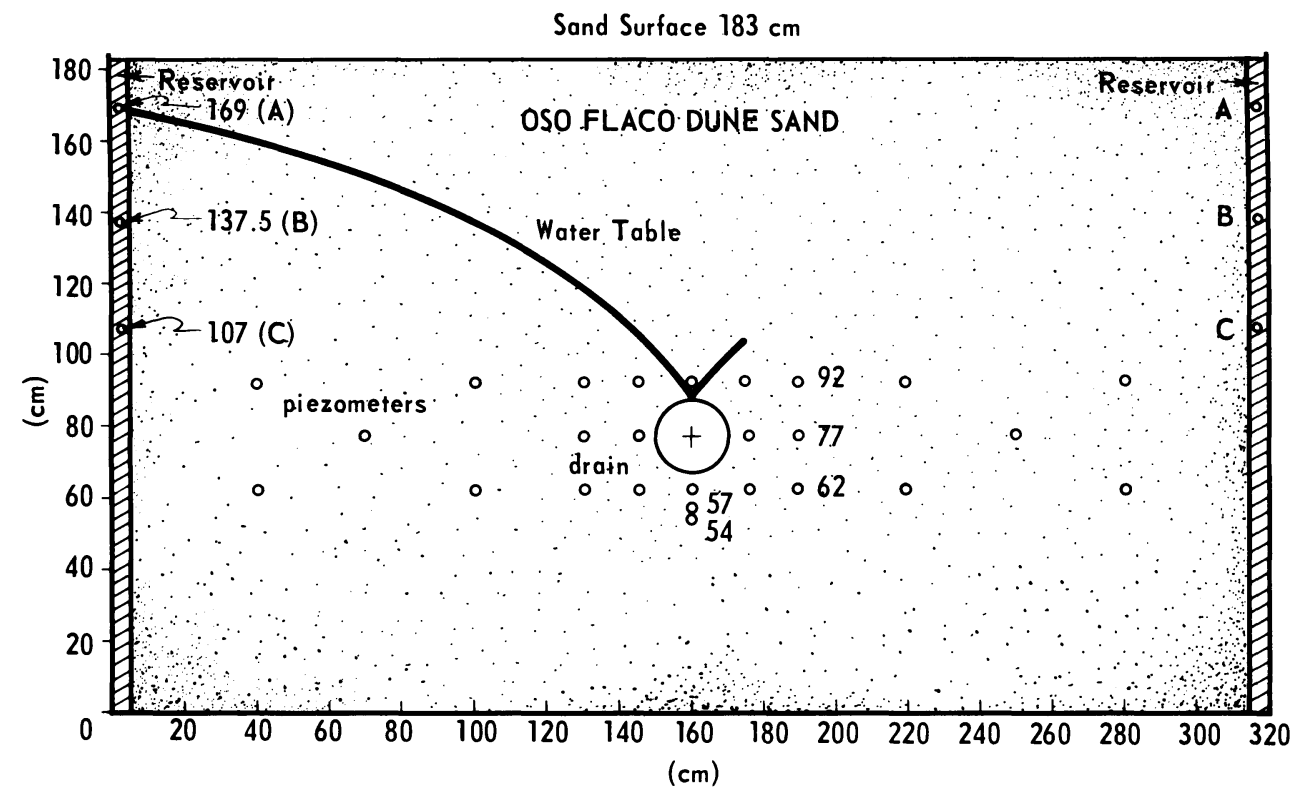

Fig. 1. Experimental tank, showing elevations with reference to bottom of tank. Small circles indicate pressure-measuring devices (piezometers). Large circle with cross indicates a removable drain. All drains were located with their centers at the cross. Reservoirs are gravel-filled and can be maintained at constant elevations (shown as $\mathrm{A}, \mathrm{B}$, and $\mathrm{C}$ ).

\section{MATERIALS AND METHODS}

Most field measurements indicate that the water table between drains is elliptically shaped. Midway between the drains the water table is relatively flat, and most of the drawdown occurs within 5 to 10 feet of the drain. For example, with a drain spacing of 100 feet and a water table height above the drain at the midpoint of 4 feet, the water table 10 feet from the drain is 2.4 feet above the drain. Five feet from the drain the water table is 1.74 feet above the drain.

To simulate the above situation, a sand-tank model was constructed as shown in figure 1. It was approximately 10.6 feet long $(322.58 \mathrm{~cm}), 3$ feet across, and 6 feet deep, with constant-level reservoirs at each end. The reservoirs simulated water tables that are $0.98,1.99$ and 3.02 feet $(30,60.5$ and $92.0 \mathrm{~cm})$ above the center of the drain at a distance of about 5 feet from the drain. These water-table heights seem reasonable as compared with the field situation.

A removable drain was located at the centerline of the tank. The tank was filled with Oso Flaco fine sand, a dune sand found near Pismo Beach, California, which has properties desirable for this experiment: lacking cohesion, it moves readily when saturated with water, filling any voids around the drainpipe and thus maintaining good and continuous contact between the drainpipe and the sand. Our observations verified this contact. Table 1 shows particle-size analysis of the sand used in a number of experiments in our laboratory. The capillary conductivity properties are described in a paper by Luthin and Day (1955).

Pressures were measured (at points 
TABLE 1

PARTICLE SIZE, OSO FLACO DUNE SAND

\begin{tabular}{|c|c|c|}
\hline $\begin{array}{c}\text { Screen } \\
\text { number }\end{array}$ & $\begin{array}{c}\text { Size range } \\
(\mathrm{mm})\end{array}$ & $\begin{array}{l}\text { Per cent } \\
\text { retained }\end{array}$ \\
\hline $40 \ldots$ & $0.840-0.420$ & 1.84 \\
\hline $60 \ldots . .$. & $0.420-0.250$ & 31.53 \\
\hline $80 \ldots$ & $0.250-0.177$ & 39.19 \\
\hline $100 \ldots . .$. & $0.177-0.149$ & 21.99 \\
\hline $140 \ldots$ & $0.149-0.105$ & 4.10 \\
\hline$\langle 140 \ldots$. & $0.105-0.00$ & 1.40 \\
\hline
\end{tabular}

indicated in figure 1) by small-bore steel tubes inserted into the tank 11.5 inches from the front side. Pressures for evaluation of exit gradients were measured by a row of piezometers spaced at 1-centimeter intervals in a vertical line immediately beneath the drain. The drains were equipped with removable weirs so that the water level in drains could be maintained at three different levels: empty, one-fourth full, and one-half full. The drain itself was made of plastic, and several different models were used. Details of each model are given in conjunction with the specific experiment for which it is used.

Fiberglass was used to simulate a gravel envelope. Earlier experiments by Watts and Luthin (1963) had shown that the permeability of compressed fiberglass is high in relation to the sand used to simulate soil. Use of fiberglass in this experiment should not be construed as a recommendation for its use in the field. Some field experience indicates that fiberglass will be sealed by clay and silt particles, which were not involved in the experiments described here.

\section{EFFECT OF DRAIN DIAMETER ON FLOW INTO THE DRAIN}

The drain consisted of plastic pipe perforated its entire length. Outer diameters of the pipe were $5.0,10.0$, and $19.0 \mathrm{~cm}$ and it was wrapped with a fiberglass mat held in place by a screen. The pipe was inserted in the sand tank. Experiments were run with the pipe end completely open, one-fourth closed, and one-half closed. This means that the water level in the pipe was zero, onequarter of the diameter, and one-half of the diameter.

\section{Results and discussion}

The effect of drain diameter on flow into drains was studied by Kirkham (1949) and reported in a classic paper for the ponded-water case. Kirkham's study was a theoretical analysis in which the drain was assumed to be flowing full of water (table 2).

Kirkham's analysis shows that doubling the drain diameter from 2 to 4 inches increases flow about 15 per cent,
TABLE 2

EFFECT OF DRAIN DIAMETER ON FLOW INTO DRAIN FOR TWO DRAIN DEPTHS AND DEPTHS TO IMPERMEABLE LAYER (KIRKHAM'S RESULTS)

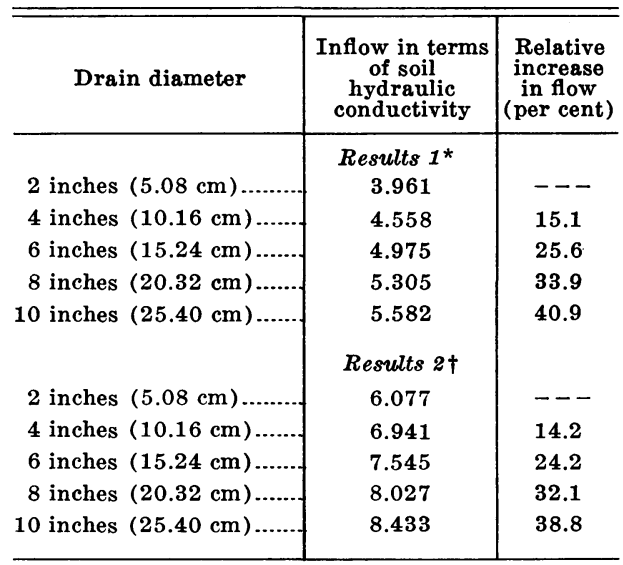

* Drain spacing, $50 \mathrm{ft}$. depth to drain center, $3 \mathrm{ft}$. depth to impermeable layer, $5 \mathrm{ft}$.

$\dagger$ Drain spacing, $50 \mathrm{ft}$. depth to drain center, $5 \mathrm{ft}$. $\dagger$ Drain spacing, $50 \mathrm{ft}$. depth
depth to impermeable layer, $9 \mathrm{ft}$. 
TABLE 3

EFFECT OF DRAIN DIAMETER ON FLOW INTO DRAIN (EXPERIMENTAL RESULTS)

\begin{tabular}{|c|c|c|c|c|c|c|c|c|}
\hline \multirow{3}{*}{$\begin{array}{l}\text { Water level } \\
\text { in reservoir }\end{array}$} & \multicolumn{2}{|c|}{$\begin{array}{l}\text { Per cent flow } \\
\text { increase for two } \\
\text { different drain } \\
\text { diameters }\end{array}$} & \multicolumn{6}{|c|}{$\begin{array}{l}\text { Drain discharge for three different } \\
\text { drain diameters and three different } \\
\text { openings (cc/sec) }\end{array}$} \\
\hline & \multirow{2}{*}{$10 \mathrm{~cm}$} & \multirow{2}{*}{$\begin{array}{l}19.0 \mathrm{~cm} \\
\text { diameter }\end{array}$} & \multicolumn{3}{|c|}{$5.0 \mathrm{~cm}$ diameter } & \multicolumn{3}{|c|}{$10.0 \mathrm{~cm}$ diameter } \\
\hline & & & open & $1 / 4$ open & $1 / 2$ open & open & $1 / 4$ open & $1 / 2$ open \\
\hline $\begin{array}{l}92 \mathrm{~cm} \text { above drain center } \\
\text { (level A) }\end{array}$ & 33.0 & 87.0 & 140.0 & 136.0 & 136.0 & 186.2 & 137.4 & 186.0 \\
\hline $\begin{array}{l}60.5 \mathrm{~cm} \text { above drain center } \\
\text { (level B) }\end{array}$ & 37.9 & 107 & 86.5 & 86.0 & 86.0 & 119.3 & 117.9 & 116.8 \\
\hline $\begin{array}{l}30.0 \mathrm{~cm} \text { above drain center } \\
\text { (level C) }\end{array}$ & 58.8 & 134.0 & 37.3 & 37.5 & 37.5 & 59.2 & 59.2 & 56.6 \\
\hline
\end{tabular}

while quadrupling the drain diameter to 8 inches will increase flow by 34 per cent. In contrast, our experiments indicate a larger effect of drain diameter on inflow (table 3 ). Doubling the diameter gave a 30 to 60 per cent increase, depending on water-table height, while increasing the diameter 3.9 times gave a 90 to 130 per cent increase, depending on the water-table height. Water level in drainpipes has little effect on drain outflow. Flow into drains is approximately proportional to reservoir water height above drain center.

The difference between theory prediction and experimental results may be due to increased energy losses in the vicinity of the drain as a result of high velocities and turbulence. Dr. Lyman S. Willardson (private communication) indicates that energy losses can result from turbulence in the vicinity of a drain. These energy losses increase as drain diameter decreases, and deviation from theory will increase as drain diameter decreases.

\section{EFFECT OF LENGTH OF PIPE SEGMENTS ON FLOW INTO DRAIN}

A segmented pipe was simulated by drilling $1 / 8$-inch holes on $1 / 4$-inch centers circumferentially at 1-foot spacings. By covering two of the rows of drain holes, the 1-foot drain could be made into a 3-foot drain. Tests were run with the drainpipe completely wrapped in fiberglass, or wrapped with strips of fiberglass covering only the rows of drain holes. Results were compared with flow into a completely perforated pipe wrapped in fiberglass.

\section{Results and Discussion}

Decreasing the pipe-segment length from 3 feet to 1 foot increased rate of flow into the pipe more than $21 / 2$ times. This increase was observed for all levels of water in the reservoirs, and for all levels of water in the drain. Wrapping the entire pipe in a fiberglass mat reduced the effect of segment length to about a 50 per cent increase. It is important to remember, however, that the sand in tank was much more permeable than soils normally encountered in the field. The relative permeability of the fiberglass mat to the permeability of field soils would be much greater. Hence, lateral flow in the fiberglass to the drain openings would largely mask 
TABLE 4

EFFECT OF SEGMENT LENGTH ON DISCHARGE RATE*

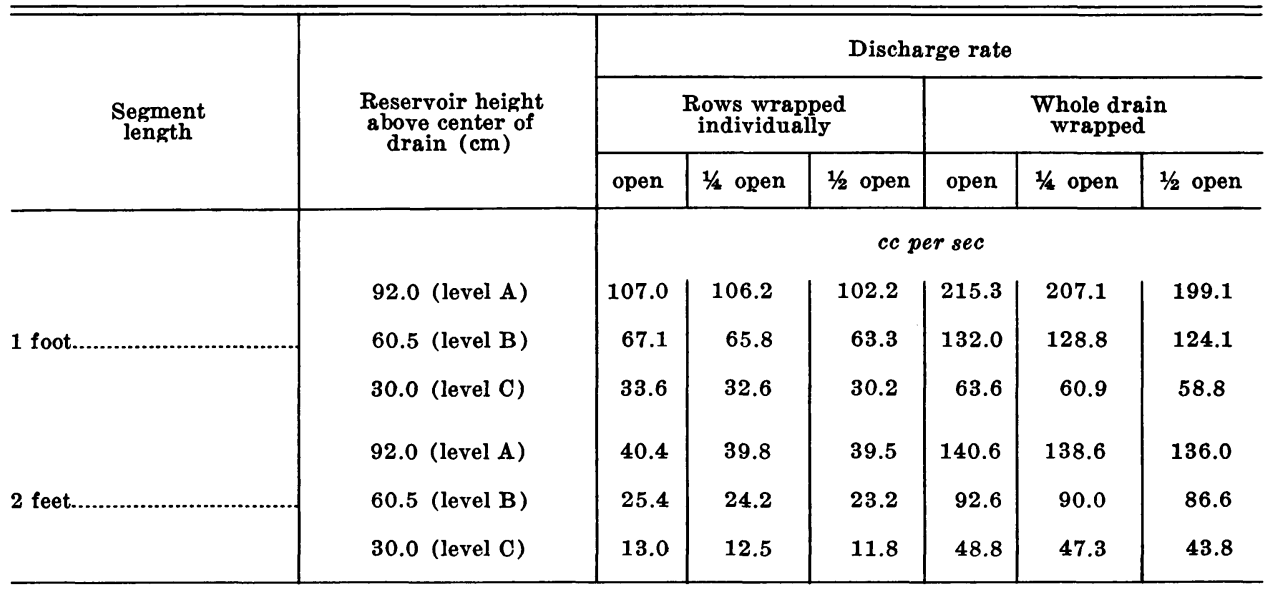

* 6" drain

the effect of pipe segment length. The same conclusions would be obtained with an envelope of gravel that completely encased the pipe. A drainpipe encased in gravel would act similarly to a completely permeable pipe, and segment length would not be of great importance in limiting flow.

The results (see figure 2 , and tables 4 and 5) are compared with flow into a pipe having 35 rows of holes in its 3 -foot section. The pipe was completely wrapped with fiberglass and was thought to be completely permeable over its surface. Figure 2 presents the results. Flow rate of the completely per- meable pipe is about 25 per cent greater than that from the wrapped 1-foot-segment pipe, and about 65 per cent greater than that from the wrapped 3-foot-segment pipe. The completely permeable pipe has a flow rate 2.34 times as great as an unwrapped 1-foot segment pipe, and 6.5 times as great as a 3-foot-long pipe segment.

Kirkham's (1950) theoretical analysis showed that encasing 1-foot pipe segments in gravel increased flow 180 per cent. The experimental data show a 234 per cent increase in flow, which is of the same order of magnitude as the theory.

TABLE 5

EFFECT OF PIPE SEGMENT LENGTH AND WRAPPING ON RELATIVE FLOWS

\begin{tabular}{|c|c|c|c|c|c|}
\hline \multirow{4}{*}{$\begin{array}{l}\text { Reservoir height } \\
\text { above center } \\
\text { of drain }\end{array}$} & \multicolumn{5}{|c|}{ Relative flows (cc per sec) } \\
\hline & \multirow{2}{*}{\multicolumn{2}{|c|}{$\frac{Q \text { (1 foot) }}{Q \text { (3 feet) }}$}} & \multirow{2}{*}{\multicolumn{2}{|c|}{$\frac{Q \text { (wrapped) }}{\mathbf{Q} \text { (unwrapped) }}$}} & \multirow{3}{*}{$\frac{\frac{Q \text { (35 rows) }}{Q(1 \text { foot })}}{\text { wrapped }}$} \\
\hline & & & & & \\
\hline & wrapped & unwrapped & \multirow{2}{*}{$\frac{1 \text { foot }}{2.00}$} & 3 feet & \\
\hline $92.0 \mathrm{~cm}(\mathrm{~A})$ & 2.65 & 1.53 & & 3.48 & 1.23 \\
\hline $60.5 \mathrm{~cm}$ (B) & 2.64 & 1.43 & 1.97 & 3.65 & 1.29 \\
\hline $30.0 \mathrm{~cm}(\mathrm{C}) \ldots \ldots \ldots$ & 2.59 & 1.30 & 1.89 & 3.76 & 1.31 \\
\hline
\end{tabular}




\section{COMPARISON OF DISCHARGE FROM \\ 1 FOOT, 3 FOOT AND 35 ROW DRAINS}

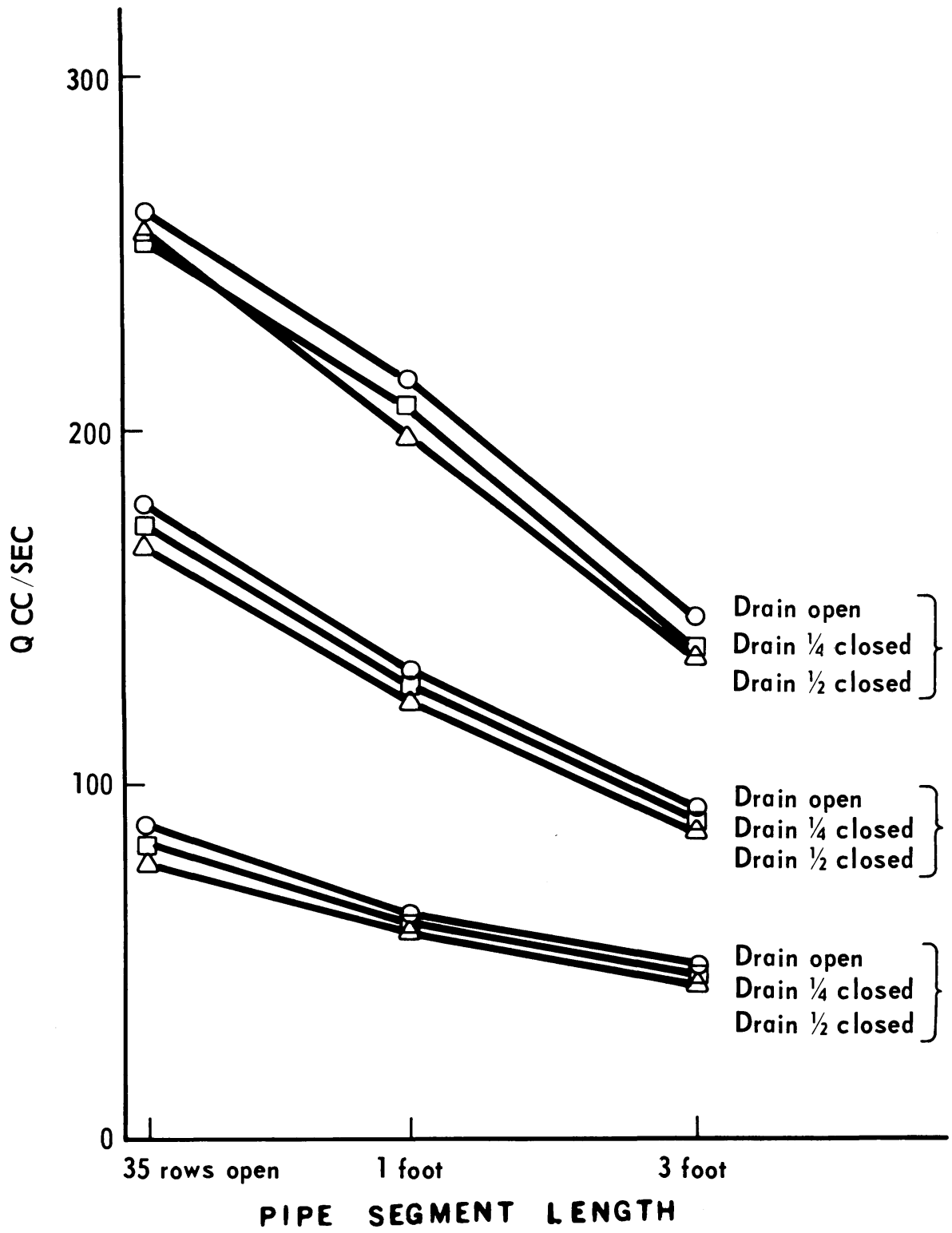

Fig. 2. Effect of pipe segment length on flow into drain. The "35 rows open" is a completely permeable drain perforated with 35 rows of holes. All drains were wrapped with glass fibers. The "drain open" is an empty drainpipe. One fourth and one half closed have weirs to maintain the water level at one fourth and one half of drain diameter. $(A, B$, and $C=$ height of water in reservoirs.) 
TABLE 6

EFFECT OF PLACEMENT OF HOLES ON FLOW INTO DRAIN

\begin{tabular}{|c|c|c|c|c|}
\hline \multirow{2}{*}{$\begin{array}{l}\text { Distance from reservoir } \\
\text { level to drain-hole } \\
\text { elevation (levels A, B, C) }\end{array}$} & \multicolumn{2}{|c|}{ Discharge rates } & \multicolumn{2}{|c|}{$\begin{array}{l}\text { Discharge rates } \\
\text { from figure } 3^{\star}\end{array}$} \\
\hline & $\begin{array}{l}\text { Holes on top } \\
\text { of drain }\end{array}$ & $\begin{array}{l}\text { Holes on bottom } \\
\text { of drain }\end{array}$ & $\begin{array}{c}\text { Discharge rate } \\
\text { calculated from } \\
\text { graph for bottom } \\
\text { drain } \dagger\end{array}$ & $\begin{array}{l}\text { Actual } \\
\text { discharge } \\
\text { rate for } \\
\text { top drains }\end{array}$ \\
\hline & \multicolumn{2}{|c|}{ ce per sec } & \multicolumn{2}{|c|}{ cc per sec } \\
\hline 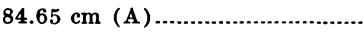 & \multirow{3}{*}{$\begin{array}{l}56.1 \\
32.1 \\
13.9\end{array}$} & \multirow{3}{*}{$\begin{array}{l}--- \\
--- \\
---\end{array}$} & \multirow{3}{*}{$\begin{array}{l}--- \\
--- \\
---\end{array}$} & \multirow{3}{*}{$\begin{array}{l}--- \\
--- \\
---\end{array}$} \\
\hline $53.15 \mathrm{~cm}(\mathrm{~B}) \ldots$ & & & & \\
\hline $22.65 \mathrm{~cm} \mathrm{(C)}$ & & & & \\
\hline $97.85 \mathrm{~cm}(\mathrm{~A})$ & \multirow{3}{*}{$\begin{array}{l}--- \\
--- \\
---\end{array}$} & \multirow{3}{*}{$\begin{array}{r}65.1 \\
41.9 \\
22.0\end{array}$} & \multirow{2}{*}{--} & -- \\
\hline $66.55 \mathrm{~cm}(\mathrm{~B})$ & & & & --- \\
\hline $36.15 \mathrm{~cm}(\mathrm{C})$ & & & --- & -- \\
\hline $84.65 \mathrm{~cm} \mathrm{(A)}$ & \multirow{2}{*}{---} & --- & 55.2 & 56.1 \\
\hline $53.15 \mathrm{~cm}$ (B) $\ldots \ldots \ldots \ldots$ & & --- & 34.5 & 32.1 \\
\hline 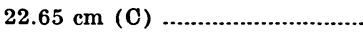 & --- & --- & 14.3 & 13.9 \\
\hline
\end{tabular}

* Rates obtained from Figure 3 as a function of water-table height for holes on top and on bottom. $\dagger$ Adjusted for total head-drop.

\section{EFFECT OF LOCATION OF DRAIN HOLES}

A 6-inch drainpipe was prepared by drilling a single row of $1 / 8$-inch holes on $1 / 4$-inch centers in a line along the drainpipe. A strip of fiberglass was taped over the row of holes to keep sand from entering them, with the tape placed so that holes were not covered. The drainpipe was placed in the sand tank first, with drain holes on top, and when the test was completed the drainpipe was placed so that the holes were on the bottom. Tests were run at three different levels of water in the drainpipe, as well as at three different levels of water in the reservoirs.

\section{Results and Discussion}

Discharge rate from the drain was greatest when the drain holes were on the bottom. However, when data in table 6 are plotted as a function of height of water table above the drain holes (figure 3 ), discharge differs very little between bottom and top locations of the holes. Thus, the difference in discharge is related to the height of water table above the point of entry into the pipe, and is not a function of location of the holes. Water level in the pipe had no effect on discharge rate when drain holes were on top of the pipe. Positioning the holes on the bottom reduced discharge rate when the water level was raised in the drain due to the change in the total driving head.

We can conclude that for a particular water-table level in the soil, the location of drain holes on the bottom of the drain will increase the discharge rate because of the increased head drop between the water-table level and the entry points in the pipe. In addition, locating the drain holes on the bottom has the advantage of draining soil to a greater depth. Sedimentation factors are not considered in this recommendation. A single row of holes gives a lower flow than is obtained by a pipe completely wrapped with permeable fiberglass material. For example, flow into the pipe with the holes on the bottom half of the pipe and for the lower height of water 


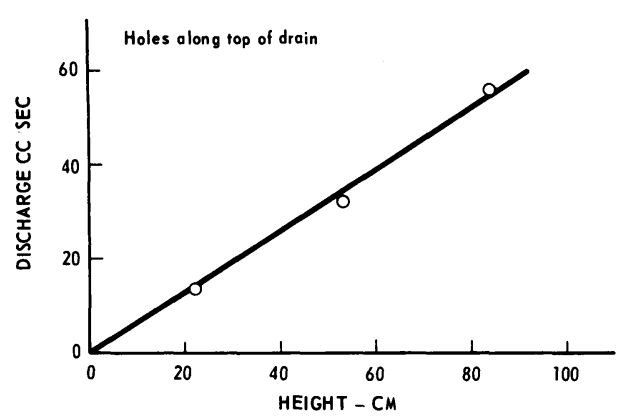

Fig. 3. Drain discharge as a function of water-table height in reservoirs for a single longitudinal line of holes in the drain. Upper chart is for the line of holes facing up; upper chart at right is for line of holes facing down.

in the reservoir amounted to 22.0 cubic centimeters per second. A pipe completely wrapped with fiberglass and completely open gave a flow of approximately 80 cubic centimeters per second. In other words, flow into the pipe is

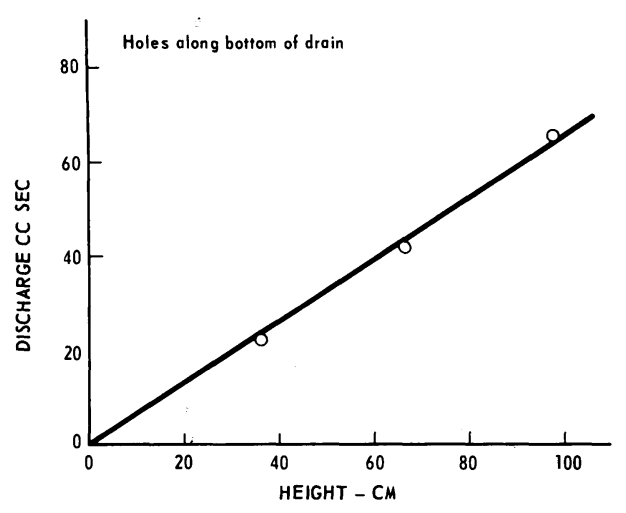

nearly four times as great with the increased access to the pipe. In some respects, it would be similar to increasing the effective diameter of the pipe, because a pipe with a single row of holes has entry points at only one location on the pipe. This effectively reduces the diameter of the pipe in terms of its capacity to collect water from the soil.

\section{RESULTS AND DISCUSSION}

\section{Water table above drain}

In all of the measurements reported here, the water table did not intersect the drain but was above the drain in every case except for the largest drain $(19.0 \mathrm{~cm})$ and for the lowest water level in the reservoir. This observation has been substantiated by measurements made in a tank 50 feet long, and also by unpublished computer solutions by Dr. George S. Taylor of Ohio State University. Most field observations indicate that the water table stands above the drain only when the drain is malfunctioning. These observations, would if valid, indicate that because of the more permeable backfill in the trench the entire trench acts as a collector of drainage water. If this is true, drain diameter may not have a significant effect on flow into drains.

It is possible that field observations above drain lines are not valid. The experiments indicate that positive pressures below the water table and above the drain do not exceed a few centimeters of positive-pressure head for drain diameters in use in the field. Field techniques used to investigate the watertable position above the drain are not adequate to measure such small pressures. Therefore, it is possible that the water table is actually above the drain even when measurements do not so indicate-in this case, drain diameter will affect flow into the drains as shown here.

\section{Effect of water-table height at mid-point on flow into drain}

In drainage theory based on the Dupuit-Forchheimer assumptions, it is assumed that drain discharge is related directly to water-table height at the midpoint between drains. A plot of the experimental data indicated that drain discharge has a straight-line relation 


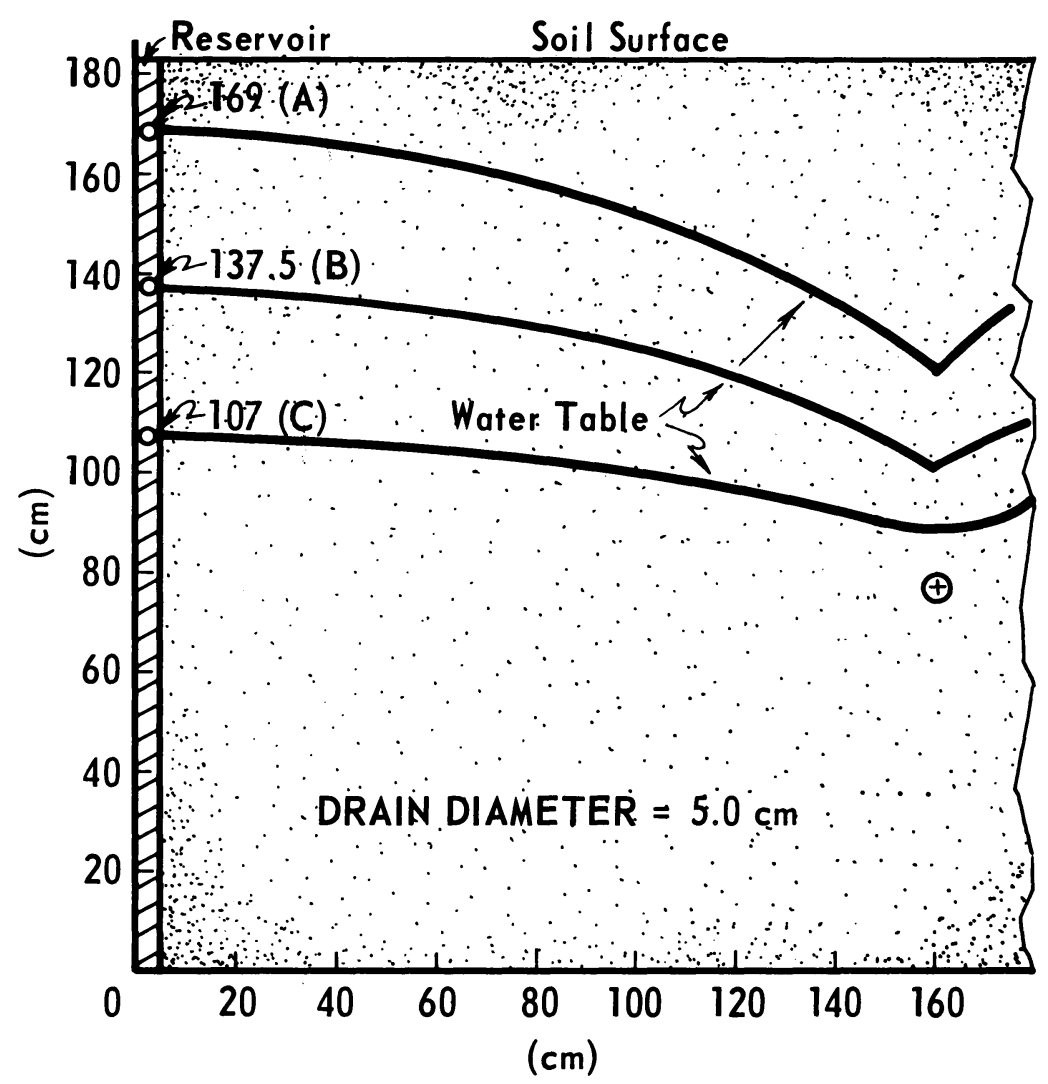

Fig. 4. Water-table positions for a $5.0 \mathrm{~cm}\left(2^{\prime \prime}\right)$ diameter drain and for three different levels of water in the reservoirs. The drain is the small circle with a cross in the middle. Note that water-table is above the drain in each case, even though drain is almost empty.

with water-table height in the reservoirs; the slope of the curves was different for different diameters. Thus, the experimental evidence supported assumptions made in the drainage theory.

Water table values for the three drain diameters are plotted in figures 4,5 and 6 , and for the three levels of water in the reservoirs. The results indicate that the water table was above the drain for the smaller drain diameters and all levels of water in the reservoir. Only with the larger drain diameter of $\mathbf{1 9 . 0}$ $\mathrm{cm}$ did the water table intersect the drain, and this was true only for the lowest water level in the reservoir.

\section{Effect of water level in drain}

The effect of a drainpipe running empty, one-quarter full, or one-half full on the rate of inflow was rather small. It appears that the main effect of increasing the depth of water in the drain was on the total hydraulic gradient. Raising the level of water in the drain decreased the hydraulic head drop and hence decreased the inflow. The effect seemed to be negligible for the cases investigated here. 


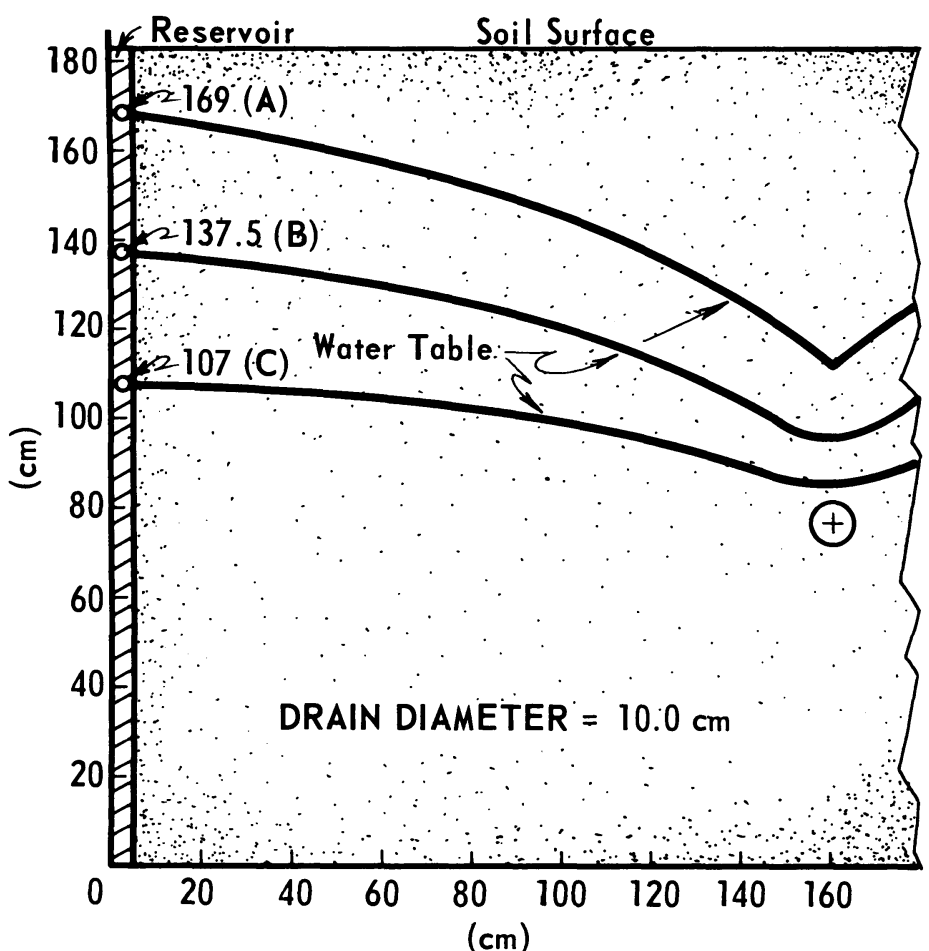

Fig. 5. Water-table positions for a $10.0 \mathrm{~cm}$ (4") diameter drain and for three different levels of water in the reservoirs.

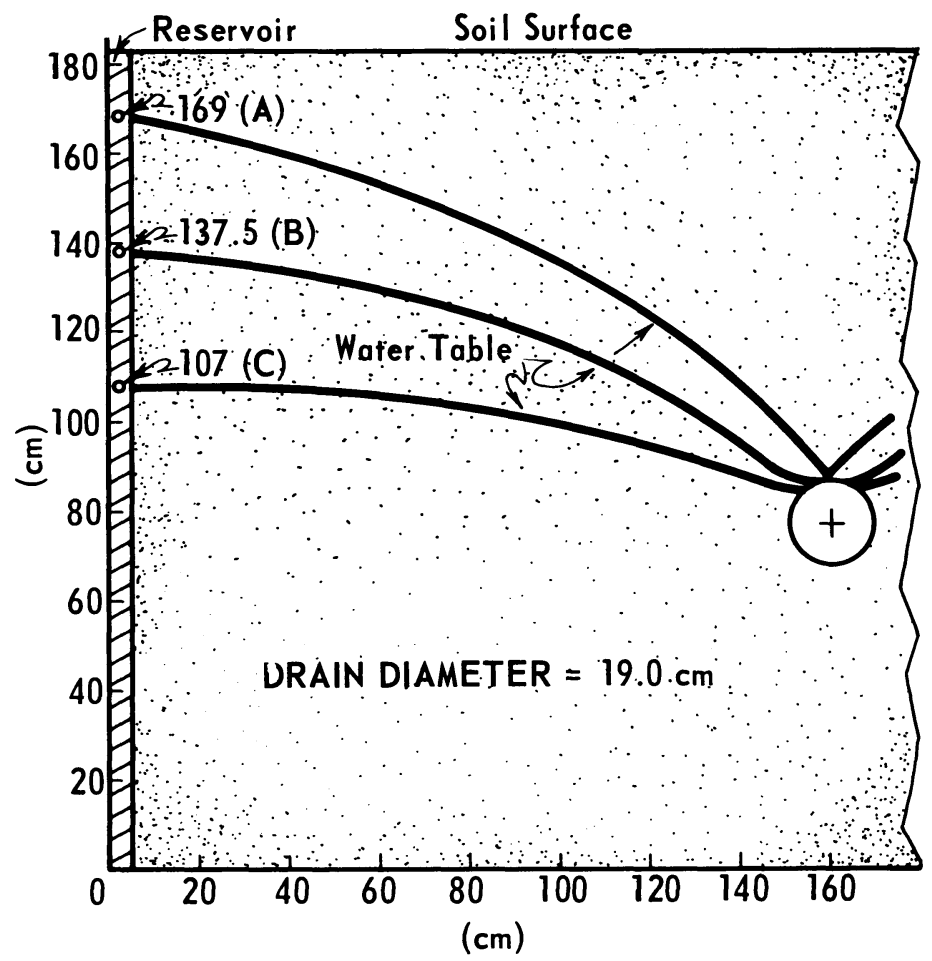

Fig. 6. Water-table positions for a $19.0 \mathrm{~cm}\left(7.48^{\prime \prime}\right)$ diameter drain and for three different levels of water in the reservoirs. 


\section{ACKNOWLEDGMENTS}

The experiments reported herein were Project W212 (OWRR No.A-031-CAL) performed by Robert Sullivan and Ah- from the Water Resources Center and mad Karbassi.

The research was supported in part by in part by Regional Research Project $\mathrm{W}-51$.

\section{LITERATURE CITED}

KIRKHAM, DON

1949. Flow of ponded water into drain tubes in soil overlying an impervious layer. Trans. Amer. Geophys. Union 30:369-85.

1950. Potential flow into circumferential openings in drain tubes. Jour. of Applied Physics 21:655-60.

KIRKHAM, D. and G. O. ScHWAB

1951. The effect of circular perforations on flow into sub-surface drain tubes. Agr. Eng. 32: (I) :211-14.

Luthin, James N. and Paul R. Day

1955. Lateral flow above a sloping water table. Soil Science Society of America Proceedings 19:406-10.

SCHWAB, G. O. and D. KIRKHAM

1951. The effect of circular perforations on flow into subsurface drain tubes. Agr. Eng. 32: (II) :270-74.

Schwab, Glenn O., Darrell W. De Boer and Howard P. Johnson

1969. Effect of openings on design of subsurface drains. Jour. of Irr. and Drain. ASCE Proc. 95:199-209. 



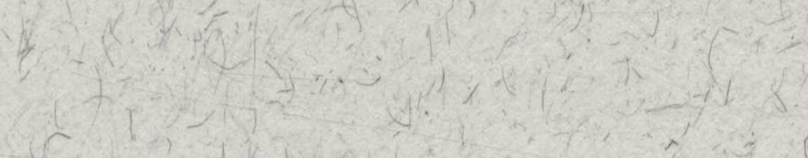

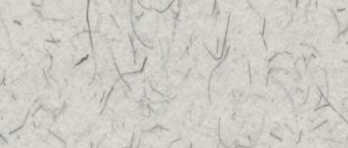

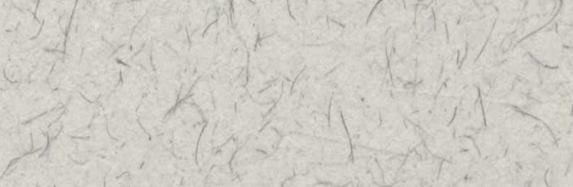

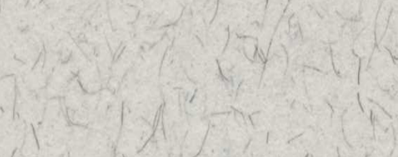

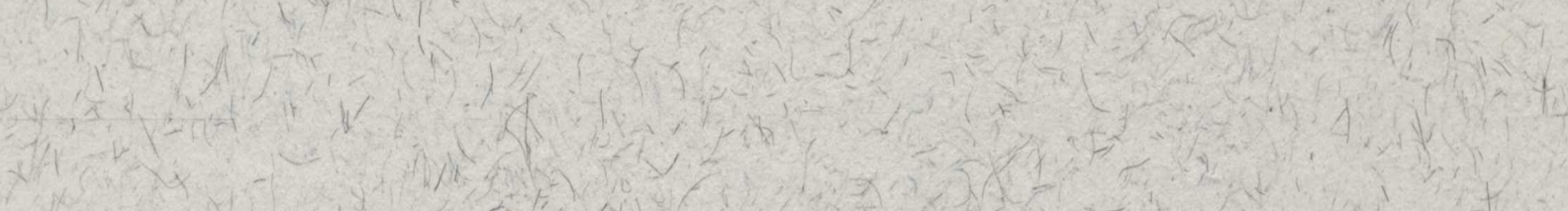

$(x)=1 x^{2}+3$

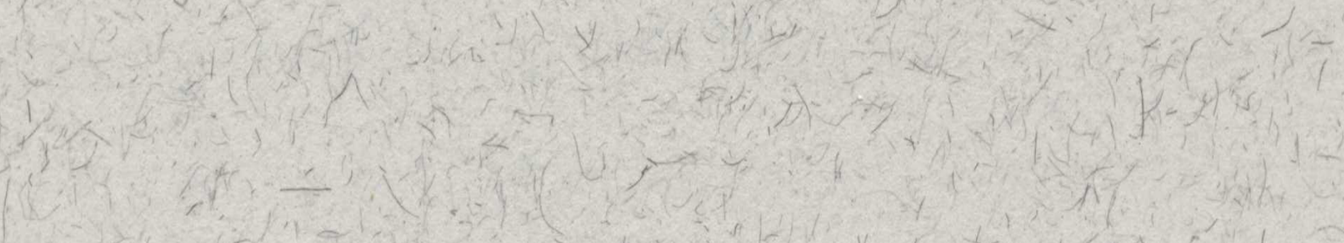

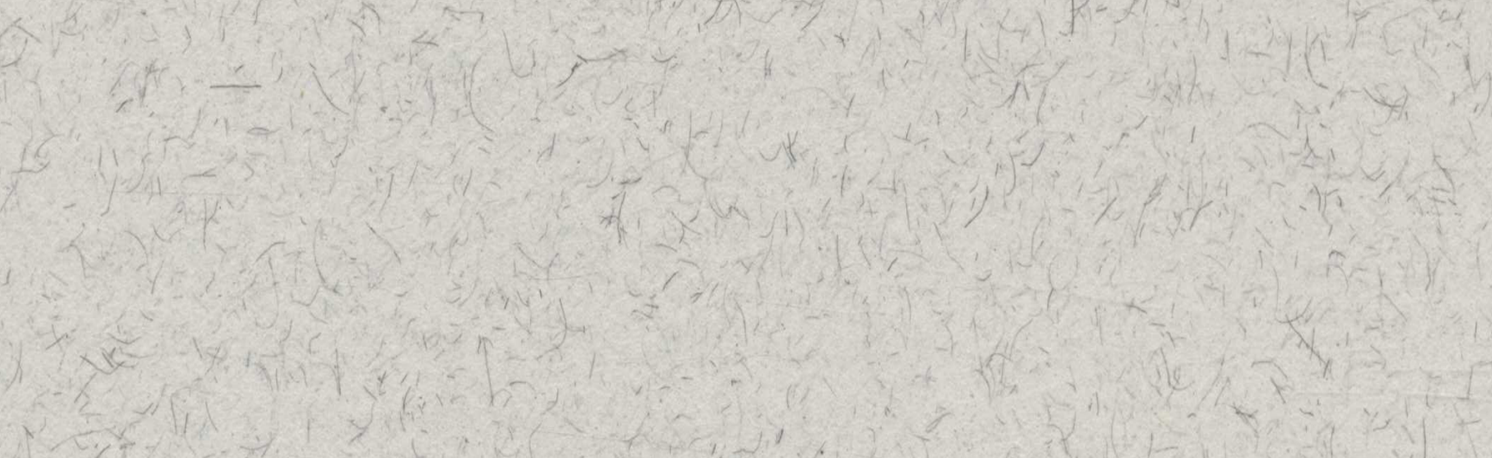
(f) 2. $^{2}+4 x^{2}+x^{2}$

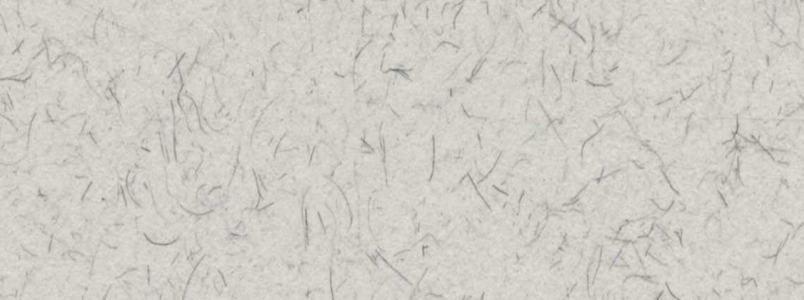

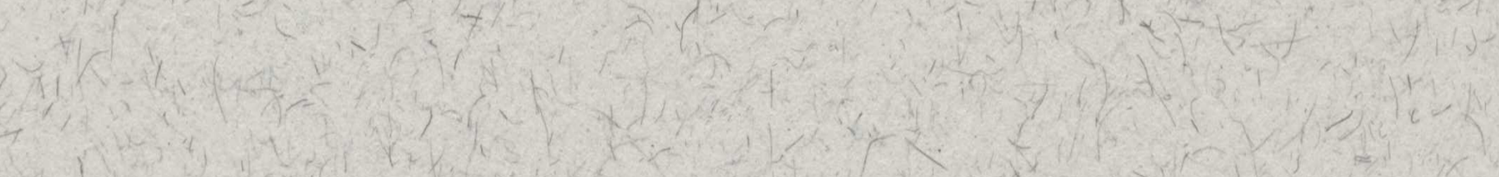


The journal HILGARDIA is published at irregular intervals, in volumes of about 650 to 700 pages. The number of issues per volume varies.

Single copies of any issue may be obtained free, as long as the supply lasts; please request by volume and issue number from:

\section{Agricultural Publications \\ University of California \\ Berkeley, California 94720}

The limit to nonresidents of California is 10 separate titles. The limit to California residents is 20 separate titles.

The journal will be sent regularly to libraries, schools, or institutions in one of the following ways:

1. In exchange for similar published material on research.

2. As a gift to qualified repository libraries only.

3. On a subscription basis $-\mathbf{\$} 7.50$ a year paid in advance. All subseriptions will be started with the first number issued during a calendar year. Subscribers starting dur. ing any given year will be sent back numbers to the first of that year and will be billed for the ensuing year the following January. Make checks or money orders payable to The Regents of The University of California; send payment with order to Agricultural Publications at above address. 